\title{
USE OF VISUALIZATION TOOLS IN THE EDUCATIONAL PROCESS
}

\author{
R. Ye. Bulyk, O.V. Kushniryk
}

HSEE of Ukraine «Bukovinian State Medical University», Chernivtsi

Key words:

visualization tools, educational process, competencies,

knowledge acquisition.

Clinical and experimental pathology 2020. Vol.19, №3 (73). P.156-160.

DOI:10.24061/1727-4338 XIX.3.73.2020.22

E-mail:

bulyk@bsmu.edu.ua, kushniryk.olha@bsmu. edu.ua

\section{Ключові слова:} засоби візуалізаиії, навчальний проичес, компетентності, засвосння знань.

Клінічна та експериментальна патологія 2020. T.19, №3(73). C.156-160.
An article integrates data on visualization tools used in the educational process of high school students, particularly in the field of medicine. The role of visualization in the formation of professional competencies of students is also shown in the paper.

Objective - analysis of scientific papers that describe the possible visualization tools in the educational process during the explanation of new material, generalization, systematization and testing of knowledge and prove their role as the acquisition of knowledge, skills and abilities of students.

Conclusions. There is a significant choice of teaching methods and tools in the arsenal of a high school teacher now, that considerably facilitates the perception of educational material by the students and contributes to its better acquisition. One of such effective methods is visualization by means of multimedia presentations, videos and interactive technologies. This approach will contribute to the better formation of the students' professional competencies, ability to analyze and think critically.

\section{ВИКОРИСТАННЯ ЗАСОБІВ ВІЗУАЛІЗАЦІЇ В НАВЧАЛЬНОМУ ПРОЦЕСІ}

\section{Р.Є. Булик, О.В. Кушнірик}

Стаття інтегрує дані про засоби візуалізації, що використовуються в навчальному процесі студентів вищої иколи, зокрема медичного профілю. У роботі також зазначена роль візуалізації у формуванні професійних компетентностей студентів. Мета роботи - аналіз наукових досліджень, щуо описують можливі засоби візуалізації в навчальному прочесі під час пояснення нового матеріалу, узагальнення, систематизації та перевірки знань і доводять їх роль як засвоєння знань, умінь та навичок студентів.

Висновки. В арсеналі викладача вищзӧ иколи зараз є значний вибір методів та засобів навчання, щзо значно полегшує сприйняття навчального матеріалу студентами та сприяє його кращяому засвоєнню. Одним із таких дієвих методів є візуалізація за допомогою мультимедійних презентацій, відеоматеріалів та інтерактивних технологій. Такий підхід сприятиме кращому формуванню у студентів професійних компетентностей, здатності до аналізу та критичного мислення.

\section{Ключевые слова: средства визуализа- ичии, учебньй прочесс, компетентности, усвоения знаний.}

Клиническая и экспериментальная патология 2020. T.19, №3 (73). C.156-160.

\section{ИСПОЛЬЗОВАНИЕ СРЕДСТВ ВИЗУАЛИЗАЦИИ В УЧЕБНОМ ПРОЦЕССЕ}

\section{Р.Е. Булык, О.В. Кушнирык}

Статья интегрирует данные о средствах визуализаџии, используемых в учебном процессе студентов высшей иколы, в частности медицинского профиля. В работе также указана роль визуализации в формировании профессиональных компетеничий студентов.

Цель работы - анализ научных исследований, описывающих возможные средства визуализации в учебном процессе во время объяснения нового материала, обобщения, систематизации и проверки знаний, что доказывает их роль в качестве усвоения знаний, умений и навыков студентов.

Выводы. В арсенале преподавателя высшей иколь сейчас есть значительный выбор методов и средств обучения, что значительно облегчает восприятие учебного материала студентами и способствует его лучшему усвоению. Одним из таких действенных методов является визуализация с помощью мультимедийньх презентаиий, видеоматериалов и интерактивных технологий. Такой подход будет способствовать лучшему формированию у студентов профессиональных компетениий, способности к анализу и критическому мышлению. 


\section{Introduction}

Modern education is impossible without the use of various teaching methods and tools that facilitate the perception of educational material and promote its better acquisition by the student audience. Among the teaching methods an important role is given to visualization with the use of multimedia technologies. Digital technologies are becoming the organic components of education and bring significant discoveries of new knowledge, principles and shifts in the perception of existing theory [5].

The purpose of using any visualization in the educational process is to promote the acquisition of certain knowledge (ideas, scientific facts, concepts, tracking of causation, etc.). In order to achieve its goal, visualization must establish a connection between the knowledge that student has and the knowledge that is taught to him. Therefore, in order to choose the effective tools of visualization, it is necessary to find out the initial level of student's knowledge, which is especially important in the context of education [11], so it is important to choose the methods and tools that are suited for studying of specific topics the best.

\section{Objective}

Of the paper is to analyze research that describes the possible tools of visualization in the educational process during the explanation of new material, generalization, systematization and testing of knowledge, and prove their role for the acquisition of knowledge, skills and abilities of students. This article also characterizes the features of visualization tools use in the education of medical students to form the competencies of the future doctor.

\section{Main part}

In recent years, many studies have been conducted on the need to strengthen of critical thinking in students of various science fields, as it has long been proven the importance and role of critical thinking for their successful development in the chosen profession [3]. In the context of higher education, a critical approach is needed, which involves an application of effective teaching methods, in particular with the use of visualization [1]. The main merits of such methods are the development of critical thinking, as well as the promotion and improvement of student learning and their success in general, making them able to solve problems in their fields [11]. Visualization motivates students to learn, making them more communicative and developing skills of a critical approach to learning material [14]. This issue becomes especially relevant in the context of training students of medical specialties, where the foreground is not only the study of a particular topic, but also the development of practical skills $[4,16]$. In addition, the visualization method helps students to develop the ability to think analytically, helping to form logical connections [2].

The specific character of teaching disciplines to medical students is to emphasize the practical significance of the knowledge, so training should be accompanied by a detailed description of the disease Клінічна та експериментальна патологія. 2020. Т.19, № 3 (73) symptoms, its clinical manifestations and features, as well as morpho-physiological characteristics of human pathogens [10]. Therefore, a variety of visualization tools come in handy, among which the most popular today are interactive technologies [6].

The application of an interactive whiteboard while training medical students is a good tool for them to master important skills in medicine [7]. In particular, conducting practical classes in medical parasitology with an interactive whiteboard allows students to examine in detail the structural elements of the human pathogen that has a diagnostic value, to find a match between the structure and functions of the structural departments [17], to establish the cause of certain clinical signs, teaches to draw logical conclusions (Fig. 1).

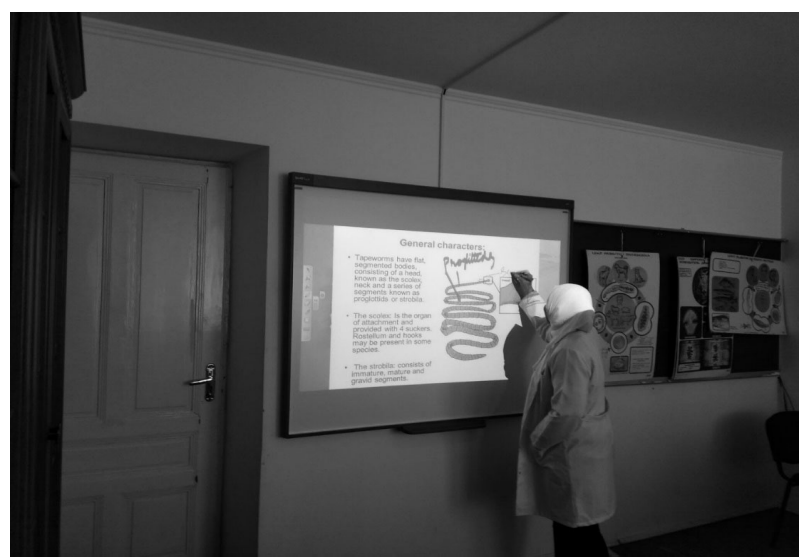

Figure 1. Use of an interactive whiteboard by students while studying medical parasitology

The advantage of using an interactive whiteboard as a new modern learning tool is the ability to integrate various learning resources effectively, improve their application, has a significant impact on improving the efficiency of communication with students' audience [20]. It should be noted the successful use of $3 \mathrm{D}$ technologies in the diagnosis of parasitic human diseases [15], which has become quite common in the development of practical skills in students. This approach proves its effectiveness in the training of future doctors, as it contributes to the formation of their professional competencies and the acquisition of the necessary knowledge, skills and abilities for further medical practice $[8,9]$.

Among the visualization tools, a prominent place belongs to multimedia presentations, various professional videos, animated videos, demonstrations of micro- and macroslides, as well as high-quality tabular resources, illustrations and diagrams $[16,18]$. One of the main purposes of using these tools, in particular animations, is to help students to build accurate mental models that can assist them to explain macroscopic observations made during practical and laboratory classes. Such a model will contribute to the formation of ideas about the mechanisms of processes occurring at the molecular level [12]. In addition, students can be asked to interpret histological and clinical images, assessing the skills of clinical diagnosis, general health and pathology indicators [19]. All these tools are publicly available and applicable in 
international educational practice. Their use is becoming increasingly important during distance learning through social distancing under pandemic conditions [13].

\section{Conclusions}

Now the arsenal of a high school teacher has a significant choice of teaching methods and tools, that highly facilitates the perception of educational material by students and contributes to its better acquisition. Nevertheless, it is important to choose the methods and tools that are the best suited for the study of a certain topic. One of such effective methods is visualization, using multimedia presentations, videos and interactive technologies. This approach will contribute to the better formation of the students' professional competencies, ability to analyze and think critically.

\section{Список літератури}

1. Alnjar HR. Data visualization metrics between theoretic view and real implementations: A review. DYSONA - Applied Science. 2020;1(2):43-50. doi: https://doi.org/10.30493/ DAS.2020.216111

2. Cullen S, Fan J, van der Brugge E, Elga A. Improving analytical reasoning and argument understanding: a quasi-experimental field study of argument visualization. npj Science of Learning [Internet]. 2018[cited 2020 Oct 12];3(1). Available from: https:// www.nature.com/articles/s41539-018-0038-5.pdf doi: https:// doi.org/10.1038/s41539-018-0038-5

3. De Jager T. Can first year student's critical thinking skills develop in a space of three months? Procedia - Social and Behavioral Sciences. 2012;47:1374-81. doi: https://doi.org/10.1016/j. sbspro.2012.06.829

4. Sisu AM, editor. Human Anatomy - Reviews and Medical Advances. 2017. Chapter 2, Fallavollita P. Innovative technologies for medical education; p. 21-36. doi: https://doi. org/10.5772/intechopen.68775

5. Ferreira H, de Oliveira GP, Araújo R, Dorça F, Cattelan R. Technology-enhanced assessment visualization for smart learning environments. Smart Learn Environ [Internet]. 2019[cited 2020 Oct 10];6:14. Available from: https://slejournal.springeropen. com/track/pdf/10.1186/s40561-019-0096-z doi: https://doi. org/10.1186/s40561-019-0096-z

6. Forbes S, Chapman J, Harraway J, Stirling D, Wild C. Use of data visualisation in the teaching of statistics: a New Zealand perspective. Statistics Education Research Journal. 2014;13(2):187-201.

7. Gouzi F, Hédon C, Blervaque L, Passerieux E, Kuster N, Pujol T, et al. Interactive whiteboard use in clinical reasoning sessions to teach diagnostic test ordering and interpretation to undergraduate medical students. BMC Med Educ [Internet]. 2019[cited 2020 Oct 12];19(1):424. Available from: https://bmcmededuc. biomedcentral.com/articles/10.1186/s12909-019-1834-1 doi: https://doi.org/10.1186/s12909-019-1834-1

8. Jamil Z, Saeed AA, Madhani S, Baig S, Cheema Z, Fatima SS Three-dimensional visualization software assists learning in students with diverse spatial intelligence in medical education. Anat Sci Educ. 2019;12(5):550-60. doi: https://doi.org/10.1002/ ase. 1828

9. Klimov D, Shahar Y. A framework for intelligent visualization of multiple time-oriented medical records. AMIA Annu Symp Proc [Internet]. 2005[cited 2020 Oct 10];2005:405-9. Available from: https:/www.ncbi.nlm.nih.gov/pmc/articles/PMC1560450/pdf/ amia2005_0405.pdf
10. Linder E, Lundin M, Thors C, Lebbad M, Winiecka-Krusnell J, Helin $\mathrm{H}$, et al. Web-based virtual microscopy for parasitology: a novel tool for education and quality assurance. PLoS Negl Trop Dis [Internet]. 2008[cited 2020 Oct 12];2(10):e315. Available from: https://www.ncbi.nlm.nih.gov/pmc/articles/PMC2565642/ pdf/pntd.0000315.pdf doi: https://doi.org/10.1371/journal. pntd.0000315.

11. Naps T, Cooper SP, Koldehofe B, Leska C, Rößling G, Dann WP, et al. Evaluating the educational impact of visualization. In: ITiCSE-WGR '03: Working Group Reports from ITiCSE on Innovation and Technology in Computer Science Education; 2003 Jun; New York. New York; 2003, p. 124-36. doi: https://doi. org/10.1145/960875.960540

12. Padilla K. Visualization: theory and practice in science education. International Journal of Science Education. 2009;31(10):141720. doi: https://doi.org/10.1080/09500690802673768

13. Reyna J. Twelve Tips for COVID-19 friendly learning design in medical education. MedEdPublish [Internet]. 2020[cited 2020 Oct 10]. Available from: https://www.mededpublish. org/manuscripts/3077 doi: https://doi.org/10.15694/ mep.2020.000103.1

14. Shatri K, Buza K. The use of visualization in teaching and learning process for developing critical thinking of students. European Journal of Social Sciences Education and Research. 2017;4(1):71-4. doi: 10.26417/ejser.v9i1.p71-74

15. Sheorey H. E-Diagnosis in medical parasitology. Trop Med Infect Dis [Internet]. 2020[cited 2020 Oct 12];5(1):8. Available from: https://www.ncbi.nlm.nih.gov/pmc/articles/PMC7157542/ pdf/tropicalmed-05-00008.pdf doi: https://doi.org/10.3390/ tropicalmed5010008

16. Silén C, Wirell S, Kvist J, Nylander E, Smedby O. Advanced $3 \mathrm{D}$ visualization in student-centred medical education. Med Teach [Internet]. 2008[cited 2020 Oct 10];30(5):e115-e24. Available from: https://www.tandfonline.com/doi/ pdf/10.1080/01421590801932228?needAccess=true doi: https:// doi.org/10.1080/01421590801932228

17. Teo BG, Sarinder KK, Lim LH. A novel alternative method for 3D visualisation in Parasitology: the construction of a 3D model of a parasite from 2D illustrations. Trop Biomed. 2010;27(2):254-64.

18. Vavra KL, Janjic-Watrich V, Loerke K, Phillips LM, Norris SP, Macnab J. Visualization in science education. ASEJ. 2011;41(1):22-30.

19. Villatoro T, Lackritz K, Chan JSY. Case-based asynchronous interactive modules in undergraduate medical education. Acad Pathol [Internet]. 2019[cited 2020 Oct 10];6:2374289519884715. Available from: https:/www.ncbi.nlm.nih.gov/pmc/articles/ PMC6823976/pdf/10.1177_2374289519884715.pdf doi: https:// doi.org/10.1177/2374289519884715

20. Yu T, Ying W, Sha K. Explore the medical curriculum teaching development in the smart classroom. International Journal of Information and Education Technology. 2017;7(2):130-4. doi: https://doi.org/10.18178/ijiet.2017.7.2.854

\section{References}

1. Alnjar HR. Data visualization metrics between theoretic view and real implementations: A review. DYSONA - Applied Science. 2020;1(2):43-50. doi: https://doi.org/10.30493/ DAS.2020.216111

2. Cullen S, Fan J, van der Brugge E, Elga A. Improving analytical reasoning and argument understanding: a quasi-experimental field study of argument visualization. npj Science of Learning [Internet]. 2018[cited 2020 Oct 12];3(1). Available from: https:// www.nature.com/articles/s41539-018-0038-5.pdf doi: https:// doi.org/10.1038/s41539-018-0038-5 
3. De Jager T. Can first year student's critical thinking skills develop in a space of three months? Procedia - Social and Behavioral Sciences. 2012;47:1374-81. doi: https://doi.org/10.1016/j. sbspro.2012.06.829

4. Sisu AM, editor. Human Anatomy - Reviews and Medical Advances. 2017. Chapter 2, Fallavollita P. Innovative technologies for medical education; p. 21-36. doi: https://doi. org/10.5772/intechopen. 68775

5. Ferreira H, de Oliveira GP, Araújo R, Dorça F, Cattelan R. Technology-enhanced assessment visualization for smart learning environments. Smart Learn Environ [Internet]. 2019[cited 2020 Oct 10];6:14. Available from: https://slejournal.springeropen. com/track/pdf/10.1186/s40561-019-0096-z doi: https://doi. org/10.1186/s40561-019-0096-Z

6. Forbes S, Chapman J, Harraway J, Stirling D, Wild C. Use of data visualisation in the teaching of statistics: a New Zealand perspective. Statistics Education Research Journal. 2014;13(2):187-201.

7. Gouzi F, Hédon C, Blervaque L, Passerieux E, Kuster N, Pujol T, et al. Interactive whiteboard use in clinical reasoning sessions to teach diagnostic test ordering and interpretation to undergraduate medical students. BMC Med Educ [Internet]. 2019[cited 2020 Oct 12];19(1):424. Available from: https://bmcmededuc. biomedcentral.com/articles/10.1186/s12909-019-1834-1 doi: https://doi.org/10.1186/s12909-019-1834-1

8. Jamil Z, Saeed AA, Madhani S, Baig S, Cheema Z, Fatima SS. Three-dimensional visualization software assists learning in students with diverse spatial intelligence in medical education. Anat Sci Educ. 2019;12(5):550-60. doi: https://doi.org/10.1002/ ase. 1828

9. Klimov D, Shahar Y. A framework for intelligent visualization of multiple time-oriented medical records. AMIA Annu Symp Proc [Internet]. 2005[cited 2020 Oct 10];2005:405-9. Available from: https://www.ncbi.nlm.nih.gov/pmc/articles/PMC1560450/pdf/ amia2005_0405.pdf

10. Linder E, Lundin M, Thors C, Lebbad M, Winiecka-Krusnell J, Helin $\mathrm{H}$, et al. Web-based virtual microscopy for parasitology: a novel tool for education and quality assurance. PLoS Negl Trop Dis [Internet]. 2008[cited 2020 Oct 12];2(10):e315. Available from: https://www.ncbi.nlm.nih.gov/pmc/articles/PMC2565642/ pdf/pntd.0000315.pdf doi: https://doi.org/10.1371/journal. pntd.0000315.

11. Naps T, Cooper SP, Koldehofe B, Leska C, Rößling G, Dann WP, et al. Evaluating the educational impact of visualization.
In: ITiCSE-WGR '03: Working Group Reports from ITiCSE on Innovation and Technology in Computer Science Education; 2003 Jun; New York. New York; 2003, p. 124-36. doi: https://doi. org/10.1145/960875.960540

12. Padilla K. Visualization: theory and practice in science education. International Journal of Science Education. 2009;31(10):141720. doi: https://doi.org/10.1080/09500690802673768

13. Reyna J. Twelve Tips for COVID-19 friendly learning design in medical education. MedEdPublish [Internet]. 2020[cited 2020 Oct 10]. Available from: https://www.mededpublish. org/manuscripts/3077 doi: https://doi.org/10.15694/ mep.2020.000103.1

14. Shatri K, Buza K. The use of visualization in teaching and learning process for developing critical thinking of students. European Journal of Social Sciences Education and Research. 2017;4(1):71-4. doi: 10.26417/ejser.v9i1.p71-74

15. Sheorey H. E-Diagnosis in medical parasitology. Trop Med Infect Dis [Internet]. 2020[cited 2020 Oct 12];5(1):8. Available from: https:/www.ncbi.nlm.nih.gov/pmc/articles/PMC7157542/ pdf/tropicalmed-05-00008.pdf doi: https://doi.org/10.3390/ tropicalmed5010008

16. Silén C, Wirell S, Kvist J, Nylander E, Smedby O. Advanced $3 \mathrm{D}$ visualization in student-centred medical education. Med Teach [Internet]. 2008[cited 2020 Oct 10];30(5):e115-e24. Available from: https://www.tandfonline.com/doi/ pdf/10.1080/01421590801932228?needAccess=true doi: https:// doi.org/10.1080/01421590801932228

17. Teo BG, Sarinder KK, Lim LH. A novel alternative method for 3D visualisation in Parasitology: the construction of a 3D model of a parasite from 2D illustrations. Trop Biomed. 2010;27(2):254-64.

18. Vavra KL, Janjic-Watrich V, Loerke K, Phillips LM, Norris SP, Macnab J. Visualization in science education. ASEJ 2011;41(1):22-30.

19. Villatoro T, Lackritz K, Chan JSY. Case-based asynchronous interactive modules in undergraduate medical education. Acad Pathol [Internet]. 2019[cited 2020 Oct 10];6:2374289519884715. Available from: https://www.ncbi.nlm.nih.gov/pmc/articles/ PMC6823976/pdf/10.1177_2374289519884715.pdf doi: https:// doi.org/10.1177/2374289519884715

20. Yu T, Ying W, Sha K. Explore the medical curriculum teaching development in the smart classroom. International Journal of Information and Education Technology. 2017;7(2):130-4. doi: https://doi.org/10.18178/ijiet.2017.7.2.854

\section{Відомості про авторів:}

Булик Р.С. - д.мед.н., професор, завідувач кафедри медичної біології та генетики Вищого державного навчального закладу України «Буковинський державний медичний університет», м. Чернівці, Україна.

Кушнірик О.В. - к.біол.н., асистент кафедри медичної біології та генетики Вищого державного навчального закладу України «Буковинський державний медичний університет», м. Чернівці, Україна.

\section{Сведения об авторах:}

Булык Р.Е. - д.мед.н., профессор, заведующий кафедрой медицинской биологии и генетики Высшего государственного учебного заведения Украины «Буковинский государственный медицинский университет», г. Черновцы, Украина.

Кушнирык О.В. - к.биол.н., ассистент кафедры медицинской биологии и генетики Высшего государственного учебного заведения Украины «Буковинский государственный медицинский университет», г. Черновцы, Украина.

\section{Information about authors:}

Bulyk R.Ye. - Doctor of Medical Sciences, Professor, Head of the Department of Medical Biology and Genetics at Higher State Educational Establishment of Ukraine «Bukovinian State Medical University», Chernivtsi. 
Kushniryk O.V. - PhD, teaching assistant of the Department of Medical Biology and Genetics at Higher State Educational Establishment of Ukraine «Bukovinian State Medical University», Chernivtsi.

Стаття надійшла до редакиії 13.08.2020

Рецензент - проф. Захарчук O.I.

(C) R.Ye. Bulyk, O.V. Kushniryk, 2020

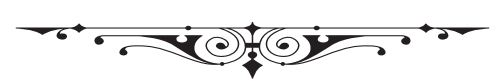

